\title{
Transition from Fire-Dependent Open Forests: Alternative Ecosystem States in the Southeastern United States
}

\author{
Brice B. Hanberry (D)
}

check for updates

Citation: Hanberry, B.B. Transition from Fire-Dependent Open Forests: Alternative Ecosystem States in the Southeastern United States. Diversity 2021, 13, 411. https://doi.org/ $10.3390 / \mathrm{d} 13090411$

Academic Editors: Michael Wink and Mario A. Pagnotta

Received: 25 July 2021

Accepted: 27 August 2021

Published: 29 August 2021

Publisher's Note: MDPI stays neutral with regard to jurisdictional claims in published maps and institutional affiliations.

Copyright: (C) 2021 by the author. Licensee MDPI, Basel, Switzerland. This article is an open access article distributed under the terms and conditions of the Creative Commons Attribution (CC BY) license (https:/ / creativecommons.org/licenses/by/ $4.0 /)$.
Rocky Mountain Research Station, USDA Forest Service, Rapid City, SD 57702, USA; brice.hanberry@usda.gov

\begin{abstract}
Land use and fire exclusion have influenced ecosystems worldwide, resulting in alternative ecosystem states. Here, I provide two examples from the southeastern United States of fire-dependent open pine and pine-oak forest loss and examine dynamics of the replacement forests, given continued long-term declines in foundation longleaf (Pinus palustris) and shortleaf (Pinus echinata) pines and recent increases in commercial loblolly (Pinus taeda) and slash (Pinus elliottii var. elliottii) pines. Shortleaf pine-oak forest historically may have been dominant on about 32 to 38 million ha, a provisional estimate based on historical composition of $75 \%$ of all trees, and has decreased to about 2.5 million ha currently; shortleaf pine now is $3 \%$ of all trees in the northern province. Longleaf pine forest decreased from about 30 million ha, totaling $75 \%$ of all trees, to 1.3 million ha and $3 \%$ of all trees in contemporary forests of the southern province. The initial transition from open pine ecosystems to closed forests, primarily comprised of broadleaf species, was countered by conversion to loblolly and slash pine plantations. Loblolly pine now accounts for $37 \%$ of all trees. Loss of fire-dependent ecosystems and their foundation tree species affect associated biodiversity, or the species that succeed under fire disturbance.
\end{abstract}

Keywords: disturbance; fire suppression; foundation; pine; plantation; pyrodiversity; savanna; woodland

\section{Introduction}

Land use and management practices have changed forest types and characteristics along with ranges and densities of tree species. Old-growth closed forests, old-growth open forests of savannas and woodlands, and old-growth floodplain forests are ecosystems that have been replaced by successional closed forests, plantations, and other land uses such as agriculture. Some tree species have decreased in density and contracted in range due to exploitative harvest, intensified agriculture, grazing, and suspension of historical disturbances that maintained historically dominant species [1]. Equally, other tree species have increased in density and expanded in range due to removal of the filtering effect of historical disturbances, opening of growing space by tree clearing, and disruption of competition from historically dominant species. Some tree species are preferred for plantations or landscaping purposes and even have become naturalized in areas outside of historical ranges; for example, conifers have a long history of use for plantings and plantations worldwide [2,3].

Fire-dependent open forests of savannas and woodlands, and their fire-tolerant tree species component, are historically abundant global ecosystems that have been affected by land use change. Low-severity surface fire was an integral disturbance for some ecosystems and surface fire was a widespread land management tool that helped maintain open forests of savannas and woodlands $[4,5]$. Conversely, the alternative state of closed forests occurs in the absence of fire [6]. Both fire and browsing by large herbivores are unique understory disturbances that remove small diameter trees and maintain herbaceous plant diversity against encroachment by woody vegetation $[6,7]$. At the same time, top-down control of resources by continuous presence of large dominant overstory trees stabilizes growing 
space against tree establishment [4]. As a result of these controls on tree biomass, open forests are characterized by simple internal stand structure consisting of a single stratum of overstory trees and limited midstory, allowing co-existence of grasslands in the ground layer [8]. Nonetheless, open forests provide complex structural diversity across regions, as savannas to closed woodlands impart the spectrum of tree densities between grasslands and closed forests [9]. Open conditions and plentiful herbaceous resources support biodiversity, encompassing unique fungi, endemic plants, insects including pollinators, and vertebrates [8-10].

Surface fire exclusion results from a combination of management and land cover changes. Active fire suppression has occurred globally along with cessation of fire as a management tool. Land use changes reduce the chance of fire occurring. Conversion to land uses with no vegetation (e.g., roads) or reduced vegetation (e.g., crops, grazing) remove fuel quantity and continuity and particularly linear barriers act as fuel breaks. In contrast, closed forests contain conditions that protect from frequent fire through limited herbaceous vegetation and reduced exposure to drying conditions required for ignition.

After surface fire exclusion, along with now frequent removal of overstory trees, some forests have shifted in state so that are no longer similar in structure, composition, and function to fire-dependent forests $[8,11]$. Closed forests contain greater tree density and tree diversity and complex internal stand structure due to multiple tree layers, but firedependent species decline without conditions that provide open structure and herbaceous plants, or even directly fire (e.g., for germination; [11]. Despite considerable conservation cost, loss of open forests remains largely unrecognized or quantified after transition to closed successional forests comprised of diverse tree species [8].

In the United States, frequent burning by Native Americans and lightning-ignited fires were a driving process in shaping the composition and structure of many ecosystems for millennia (Figure 1). One of the first observations in Euro-American historical accounts was that native humans burned wildlands [12]. Indeed, Euro-American settlers typically adapted native burning practices and some settlers may have experienced fire as part of pastoral management before emigration [13-15]. Nonetheless, forests were harvested rapidly due to steam power, railroads, and inexpensive land prices starting about 1860 . By 1920, most forestlands in the United States either were cleared or disturbed by harvest for wood products, and additionally, fire exclusion became institutionalized. Although other drivers such as climate and herbivory, or a combination of factors, have been invoked to explain states and state transition, fire exclusion is a key mechanism that holds up to available evidence for the eastern United States during the past thousands of years, after extinction of almost all megaherbivores [16].

Closed successional forests have become the current baselines, along with overstory tree removal as the primary disturbance, resulting in continuous successional cycles and designation of species as successional [17]. And yet, overstory tree disturbance was uncommon in the past as trees that reached the overstory often lived hundreds of years [18]. For example, hurricane return intervals along the Atlantic Gulf Coast are approximately 320 years [19] and low-density forests, particularly of drought-tolerant species, are more resistant to drought, wind, and insects than closed, high-density forests with mesic tree species and high contrast edges [20-22]. Similarly, species considered edge or successional, such as some bird species, use both herbaceous and woody resources, which are spatially separated in current landscapes of closed forests and clearings, but in fact coexisted in historical open forests [23]. 


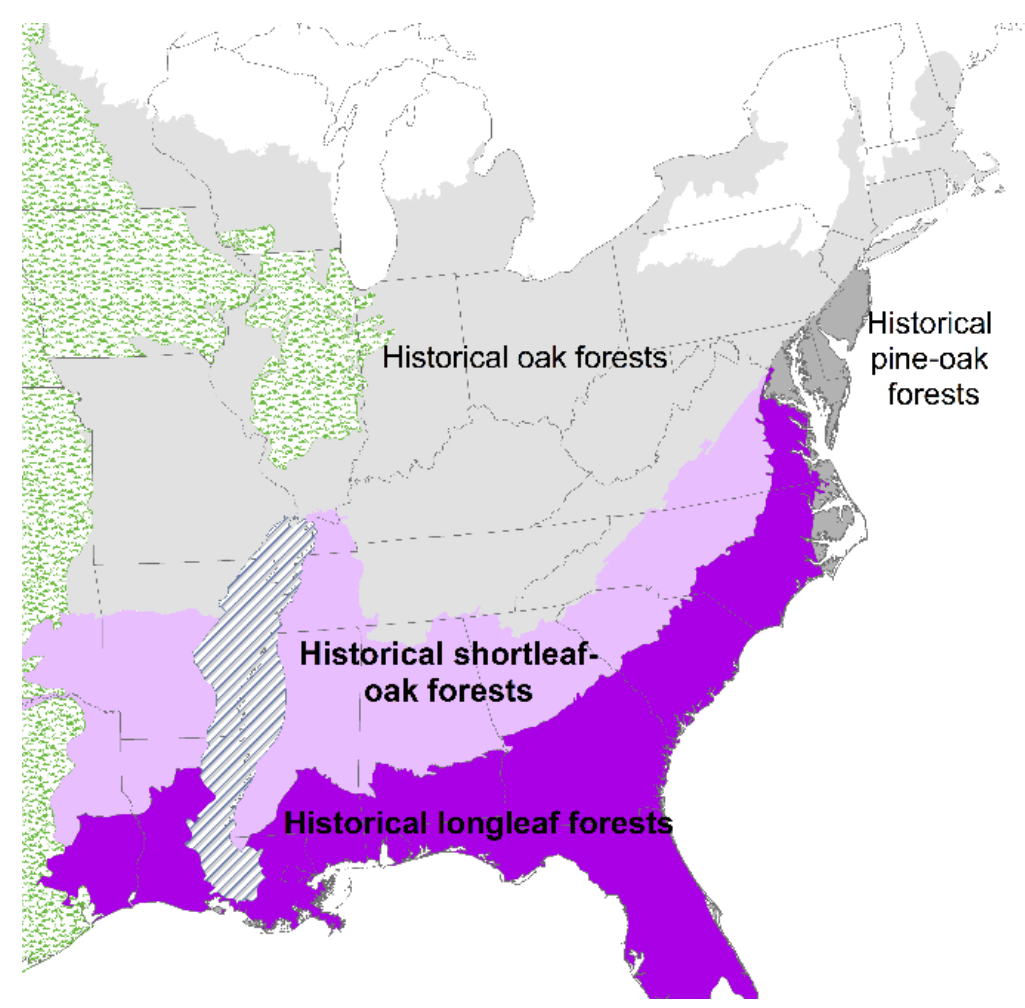

Figure 1. Generalized depiction of primary historical ecosystems in the eastern United States (modified from [24]). Historical surface fire-dependent open longleaf pine or shortleaf pine-oak forests dominated the southern and northern ecological provinces (shaded light and dark purple) of the southeastern United States. Open oak forests (most of the central eastern region shaded gray, although closed forests of shade-tolerant species co-occurred in this region) and grasslands (the central United States, shaded green) also were maintained by frequent surface fires, while pine-oak forests (dark gray) probably relied on a mixed severity fire and wind regime, and boreal forests (portions of the white, non-shaded northernmost region) auto-replaced after high severity fire every 50 to 150 years. In other parts of the northernmost region, fires occurred $>1000$ years, resulting in disturbance-independent closed forests. Floodplain forests in the Lower Mississippi Alluvial Valley (striped) experienced fire that spread from adjacent uplands but were more influenced by flooding disturbance.

Fundamental research in the dynamics and patterns of species help establish open forest loss and impacts of current novel forests. Here, I summarized loss and transition of fire-dependent open forests in the southeastern United States and quantified recent developments in pine densities and ranges during a 30-year interval, approximately 1979 to 2007. Commercial loblolly and slash pines and historically dominant longleaf and shortleaf pines are the principal pine species of southeastern mixed forests, due to either current or historical greatest abundances, and all appear to be undergoing continual dynamics in density and potentially in range. Oswalt et al. [25] comprehensively documented longleaf pine dynamics, but for convenience of comparison, I also provide longleaf pine information.

\section{Loss of Fire-Dependent Pine and Pine-Oak Forests and Replacement by Broadleaf Forests and Pine Plantations}

Fire-dependent open forests of savannas and woodlands historically were dominant in the southeastern United States, where fires typically occurred every 2 to 15 years at any given place $[8,26,27]$ of Figure 1 . Longleaf pine was the foundation species $(>75 \%$ of all trees) in the southern ecological province of the southeastern region, although this included some percentage of other, less fire-tolerant pine species that may have been dominant in localized areas [28-31]. Longleaf pine forests historically were dominant across about 
30 million ha [29]. Shortleaf pine, at about 35\% of all trees (including some other pine species), combined with several fire-tolerant oak species (e.g., Q. stellata), comprising $40 \%$ of all trees, were the foundation genera of the northern province of the southeastern region [32]. These dominant species defined the ecosystem, determined abiotic conditions, and supported biological communities $[8,33]$. Open longleaf pine forest specifically remains known for associated biodiversity, with 150 to 300 grass and forb species per hectare, including rare and 1630 endemic plant species, although some of the same species were supported by open forests throughout the eastern United States $[1,8,9]$.

Following Frost's [29] calculation for longleaf pine forests, a rough estimate of the historical extent of shortleaf pine-oak dominance may be about 32 to 38 million ha, given these species were $75 \%$ of all trees across an upland land area of 42 million ha, excluding wetlands, in the northern province of this southeast region. This is a provisional estimate based on information available from historical tree surveys, which are incomplete, but reinforced by historical accounts [34,35]. For example, Mohr and Roth (34:93) wrote that shortleaf pine was equally abundant as longleaf pine but covered a greater extent than longleaf. Future research may result in adjustments. In particular, both open longleaf and shortleaf-oak forests probably were interspersed with numerous grassland patches of varying size, which cumulatively may have totaled about 7 to 8 million ha in each of these regions.

Historical information about loblolly and slash pine is limited. Loblolly was locally dominant in places such as eastern North Carolina in the moist soil of swamps (34:117) and generally loblolly pine was located in wet and wetland sites that offered protection from frequent fire, sheltering with other tree species that comprised a small fraction of forests in the southeastern United States [28-31]. For example, Mattoon (35:3) described loblolly as "growing along the watercourses and on low heavy soils", until expanding into old fields that were cleared of shortleaf pine. Similarly, excepting where fast-growing loblolly established on old fields and developed into second growth forests in replacement of longleaf pine, loblolly grew along swampy borders and floodplains, in badly drained tracts of moist soil, or well-dispersed among other species (34:117-119). Consequently, loblolly pine may have been one to two percentage of all trees, which is about the greatest abundance attained in the past by species rarely able to survive frequent surface fires when vulnerable at the small diameter stage [26,27]. Loblolly pine is less fire-tolerant than slash pine, but slash pine still was constrained to wet locations, until the combination of longleaf pine removal and fire exclusion permitted expansion to drier sites, particularly abandoned fields [36]. Stoddard [7] wrote: "Longleaf could not reproduce in the "rough" after the burning was stopped, although the Slash Pine, in partially wet ground, continued to seed in following the stopping of fire use. Where the few seed trees included Slash, it took over most of the Longleaf sites. This was the most tragic angle of the fire exclusion and was largely responsible for the terrific damage done by the wildfires during the great droughts of the 1930's and the 1950's." Slash pine additionally is restricted in distribution to the warmer southernmost locations, primarily Florida.

After fire-dependent forests were cleared for forest products and agriculture during Euro-American settlement, generally by 1920 (Figure 2), followed by surface fire exclusion, new forests of broadleaf tree species grew in replacement [11,37]. Hundreds of broadleaf tree species occur throughout the eastern United States, but most species cannot survive frequent fire regimes when vulnerable as small diameter trees and historically were confined to fire-free areas. Opening of growing space through tree removal combined with removing of the fire filter allowed broadleaf trees to establish and compete for resources through fast growth. In addition to a greater diversity of fire-sensitive species, these forests characteristically have greater small diameter tree density, and two to three-fold greater larger tree $(\geq 12.7 \mathrm{~cm}$ in diameter) density than open forests. Trees throughout the vertical profile replace open conditions while uncontrolled small diameter trees displace herbaceous plants [8]. 


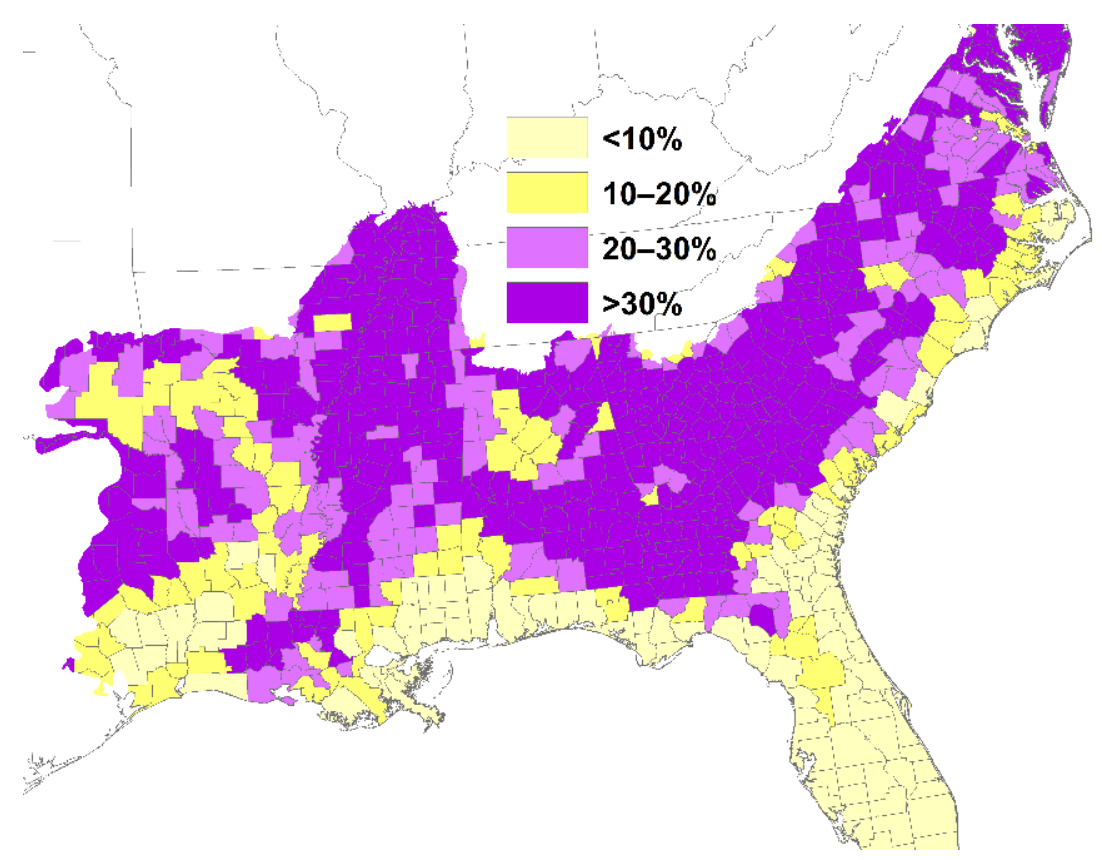

Figure 2. Percent of land in agriculture by county during 1920 (modified from [38]).

Longleaf pine forest has decreased from about 30 million ha to 1.3 million ha or 1.7 million ha with oak $[25,29]$ while shortleaf pine-oak forest has decreased from about 32 to 38 million ha to about 2.5 million ha [39]. Longleaf and shortleaf pines are about $3 \%$ of all trees in the southern and northern provinces of the southeast region, respectively. Most of the remaining forests likely are degraded, with biodiversity loss through fire exclusion, fragmentation, overgrazing, and non-native plant invasions. For example, prescribed burning may occur on about 200,000 ha of existing longleaf pine lands and only about 100,000 ha of longleaf may remain without significant loss of biodiversity $[4,40]$.

The southeastern United States now is the greatest producer of forest products worldwide due to the long growing season and intensive management that allow the full cycle from pine planting to harvest to occur within 20 to 25 years [41]. Pine plantations have become progressively more common since 1950 [37,40], reversing conversion to broadleaf forests in the southeastern region (Figure 3). In the southeastern U.S., pine plantations covered 0.8 million ha in 1952, 8.5 million ha in 1987, 12 million ha in 1999, and 17 million ha in 2017 [37,42-44]. Pine plantations generally consist of loblolly or slash pine that are the most profitable species, particularly in marginal lands for agriculture, although plantations of shortleaf and longleaf pine occur when multiple objectives (e.g., wildlife, hunting) are of interest to landowners $[45,46]$.

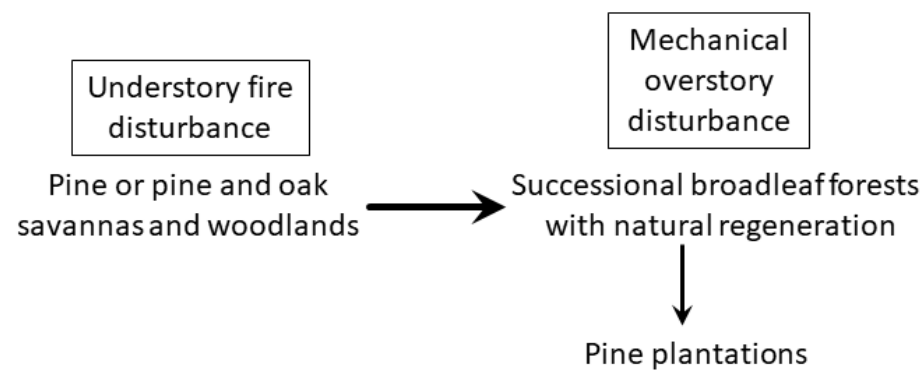

Figure 3. Change of disturbance type and disturbance-dependent forests, from fire-dependent pine or pine-oak forests to successional broadleaf forests, which subsequently were converted to pine plantations. 
Briefly, for recent dynamics, I used the USDA Forest Service Forest Inventory and Analysis National Program [47] to assess trees $\geq 12.7 \mathrm{~cm}$ in diameter (at $1.4 \mathrm{~m}$ above ground height). The national sampling design encompasses thousands of long-term plots located about every 2000-2500 ha across the country [48]. Although it is possible to use adjustments to compensate for standardization of FIA survey methods (detailed in [49]), survey results are relatively robust in forested regions such as the southeastern United States and adjustments for some species may cause deviation from the most recent survey information.

Loblolly pine has become the most abundant species, totaling about $35 \%$ of all trees, in the southern province of the southeast region. Slash pine is the second most abundant at about $13 \%$ of all trees. And, in the northern province of the southeast region, loblolly pine has become the most abundant species, at about $42 \%$ of all trees. Current range for loblolly pine is 126 million ha (Figure 4; range defined here as where a species is present at $\geq 0.5 \%$ of all trees in an ecological subsection, which are smaller ecological units [50]. Loblolly pine expanded 9 million ha in range, while area where loblolly was present at $\geq 30 \%$ of total species composition almost tripled, increasing from 24 million ha to 64 million ha, a total increase of by 40 million ha (Figure 5). Range for slash pine was 41 million ha, a decrease of 21 million ha, although mean percent composition within its range increased. Northern Florida is the center of slash pine plantations and increased composition from plantations offset percent composition decreases and contraction in slash pine's northern range.

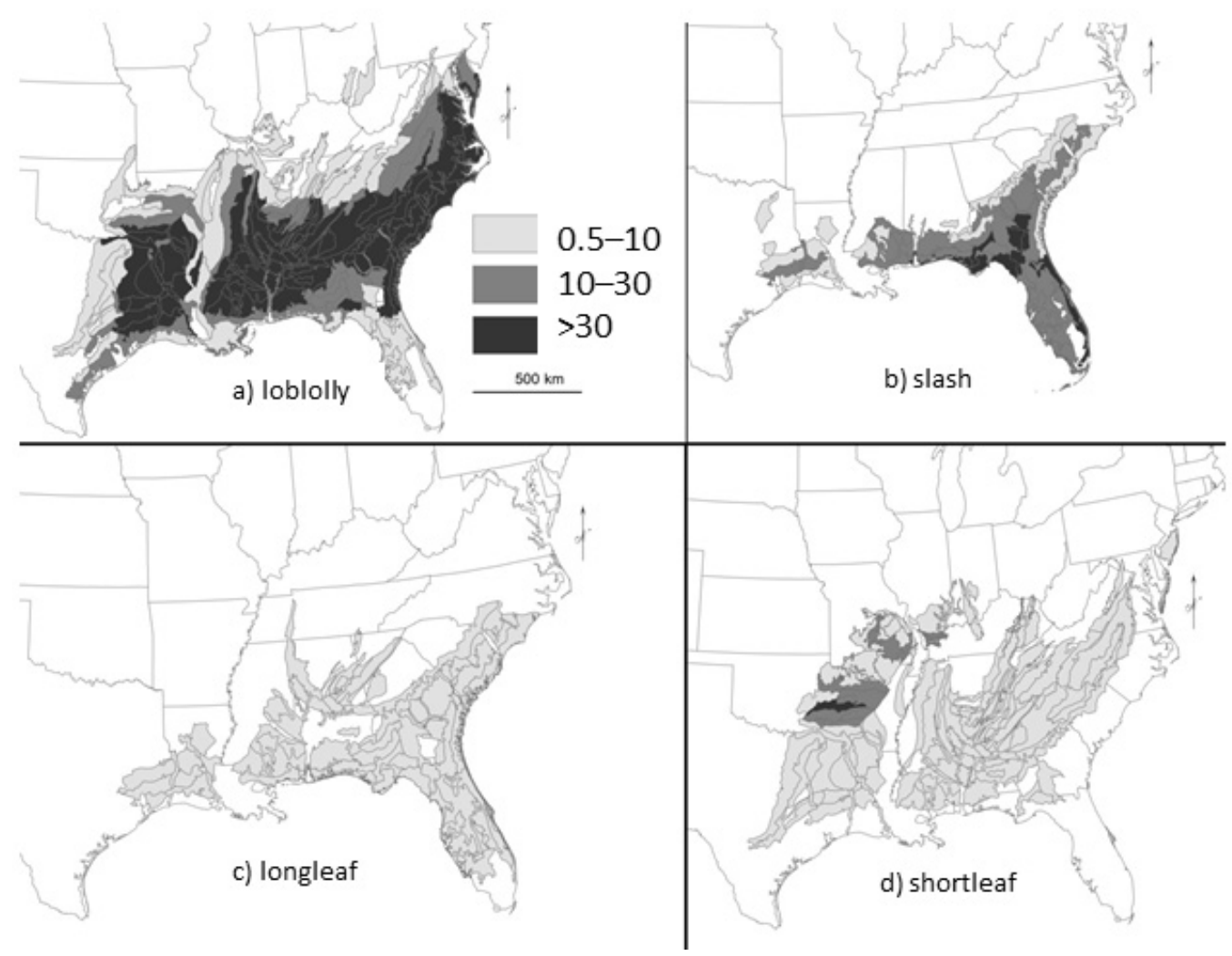

Figure 4. Current ranges (percent composition $\geq 0.5 \%$ of all trees in an ecological subsection, which are shaded) and three groupings of abundance by percent composition in ecological subsections for the four pine species. 


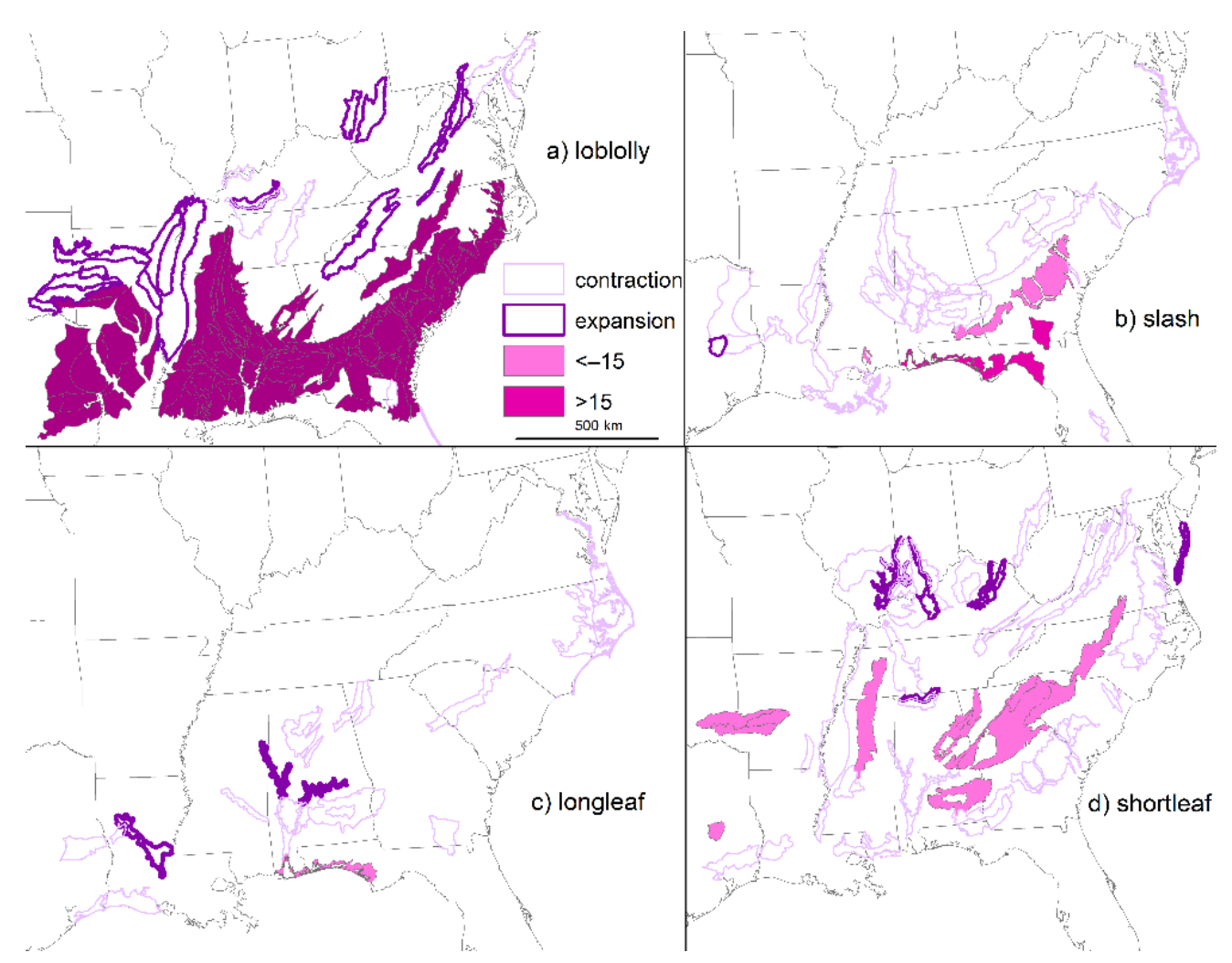

Figure 5. Areas of contraction (thin light purple outline) or expansion (thick dark purple outline) in range (percent composition $\geq 0.5 \%$ of all trees in an ecological subsection) and areas of relative decrease by $>15$ percentage points (pink shading; out of 100 percentage points for composition of all trees) or increase by $>15$ percentage points (dark pink shading) in ecological subsections for the four pine species. Note that some ecological subsections are discontinuous and comprised of multiple spatial units.

Conversely, current range for longleaf pine was 48 million ha, a decrease of 9 million ha, and mean percent composition decreased. Additionally, longleaf pine was no longer a dominant species (defined here as $\geq 10 \%$ of total species composition by ecological subsection), losing dominance over 6.0 million ha. Range for shortleaf pine was 90 million ha, a decrease of 25 million ha, and mean percent composition decreased. Furthermore, shortleaf pine decreased in area of $\geq 10 \%$ of total species composition by 40 million ha.

Range dynamics are complex and vary in shape due to multiple attributes, including areal extent, density, spatial variation, discontinuities, and user-defined thresholds and spatial units. An idealized range, at least based on range maps from pollen studies of tree response to changing climate, is continuous with greater densities toward the center of the range, so that movement along a leading edge is easily measured. But all of the pine ranges were discontinuous, and in particular, disrupted by the floodplains of the Mississippi River Alluvial Valley (Figure 1). Pine species, in general, do not have the traits to compete well against angiosperm tree species in fertile alluvial soils or against flood-tolerant tree species in floodplains. The Mississippi River Alluvial Valley also has been converted to agriculture, a land use that fragments tree distributions, and likely more pines have been planted in the Lower Mississippi River Alluvial Valley than occurred historically during the 1800s [51]. Different ecological features, whether floodplains or mountains, will divide ranges, regardless of land use. Additionally, each of the pine ranges had unique spatial variation in relative densities, ranging from relatively uniform for longleaf pine to greater percent composition in the northwestern part of shortleaf pine's range. Range contractions for longleaf pine during the study interval, although disjunct, were spread evenly across the Coastal Plain. In contrast, shortleaf pine range is concentrated on the west side of 
the northern province and range contractions occurred to the east of the densest portion of shortleaf pine range. Loblolly pine, a major commercial pine species, expanded and increased in composition but conversely, the other major commercial species, slash pine, contracted in range but increased in percent composition where it was planted.

Where loblolly increased during recent decades, primarily other pine species decreased rather than fire-sensitive broadleaf species, which currently represent about $40 \%$ to $45 \%$ of species in the southeast region. In the 51 ecological subsections where loblolly pine increased by $\geq 5$ percentage point of all trees, shortleaf pine decreased by $\geq 5$ percentage point of all trees. Slash pine, Virginia pine (Pinus virginiana), swamp tupelo (a floodplain broadleaf species; Nyssa biflora), sweetgum (a broadleaf species; Liquidambar styraciflua), longleaf pine, and pond pine (Pinus serotina) decreased in five to 11 subsections where loblolly pine increased by $\geq 5 \%$ of total species composition.

Harvest accelerated tree replacement, but a long time remains necessary for trees to reach new competitive dynamics after a state transition, as demonstrated by continuing longleaf and shortleaf pine reductions in composition and contraction in range during recent decades. Many species have increased after the historically dominant, fire-tolerant pine and oak species that comprised $75 \%$ of all species decreased in the southeast region, but only five species are $\geq 3 \%$ of all trees throughout the region out of 180 tree species, in part because of the relative dominance of loblolly pine, at $37 \%$ of all trees, and abundant slash pine, at $6 \%$ of all trees. In the central eastern region (Figure 1; north of the southeastern region), which has transitioned from open oak-dominated forests with some inclusion of old-growth closed forests, ten species are $\geq 3 \%$ of all trees, with red maple (Acer rubrum) dominant at $11 \%$ of all trees, out of 180 tree species. Loblolly pine plantations currently are rare in this region, despite some expansion and contraction in dynamics, although that is likely to change in the future.

Evergreen forest, which primarily is coniferous, remained stable at $24.3 \%$ of land area in the southern province of the southeast region, comparing land cover of 2001 to land cover of 2016 [52] of Figure 6. Evergreen forest increased from 18.4\% to 19.3\% of land area in the northern province of the southeast region. Although this may not appear to be much, the land area is 46 million ha, or 42.1 million ha excluding wetlands, and therefore, gain in evergreen forest was about 400,000 ha.

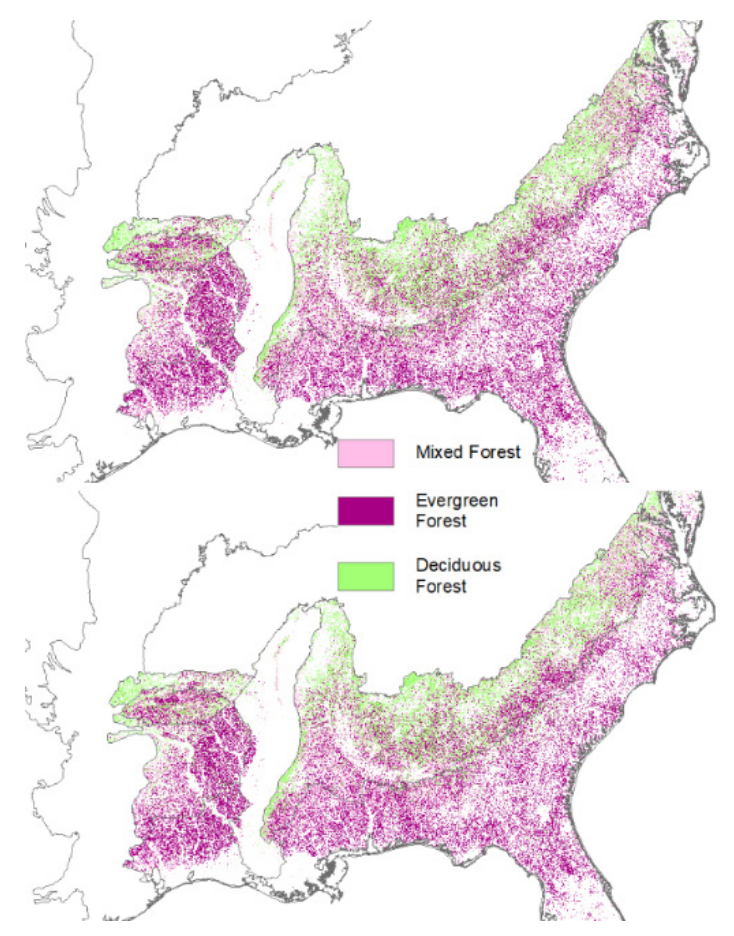

Figure 6. Forest land classes during 2001 (upper panel) and 2016 (lower panel). 


\section{Implications for Management and Conservation}

In summary, the southeastern United States is an example of transition between alternative states, from open forests dominated by a few fire-tolerant tree species to closed forests comprised of a diversity of primarily fire-sensitive broadleaf species and loblolly and shortleaf pine plantations. Open fire-tolerant shortleaf pine-oak forests historically dominated about 32 to 38 million ha, at $75 \%$ of all trees in the northern province of the southeastern United States, but have decreased to about 2.5 million ha, with shortleaf pine comprising 3\% of all trees and fire-tolerant oaks at about $8 \%$ of all trees [32,53]. Open longleaf pine forest decreased from being dominant in about 30 million ha, and $75 \%$ of all trees, to 1.3 million ha, and $3 \%$ of all trees in the southern province of the southeastern United States. The alternative open and closed states occurred before and after change in land management, from frequent low-severity fire that controls understory trees to fire exclusion. Fire exclusion often is accompanied by constant overstory tree removal, for land use and forest products, which prevents closed successional forests from becoming closed old-growth forests comprised of a few very shade-tolerant and long-lived species. Additional land use has converted naturally regenerated, primarily broadleaf closed forests to loblolly and slash pine plantations in the southeast region. Despite minor presence historically and a limited range, loblolly pine now is the most common species in the eastern United States. Continued expansion of loblolly pine plantations has occurred in the northern province and loblolly pine plantations have become more abundant where they already occurred, as loblolly pine increased 40.2 million ha where it was $\geq 30 \%$ of total species composition. Likewise, slash pine increased in composition within its current range, although slash pine ranges overall contracted, indicating that the current margins where slash pine plantations are profitable have been reached.

The southeastern United States is not the only region with locations that display pine dynamics [54-66]. That is, where historically dominant pine species contract in range and rarify in density due to changes in the historical fire regime or other changes in land use that release fire-sensitive species. Land conversion to pine plantations may counteract the state transition to fire-sensitive naturally regenerated species, redirecting a process and shifting pine ranges.

Pine plantations may be a closer analogue than closed forests to historical open pine ecosystems because regular stand-replacing disturbance results in regenerating stands with open conditions in short rotations, albeit the conditions close quickly because of intensive management. Management to control angiosperm regeneration extends the duration of open forests ecosystems with an herbaceous understory; conversely, if management intensity is too great (i.e., site preparation with herbicide applications and mechanical treatments, followed by further herbicide applications after planting) then plantations will be dominated by fast-growing pines with little development of an understory or wildlife presence [67]. Resemblance to stable open pine ecosystems can be enhanced by tree retention at harvest to provide biological continuity [4]. Given enough time and careful tree retention through multiple rotations, scattered large diameter trees will develop, perhaps even longleaf pine along edges. Live, old longleaf pine trees eventually may attract federally endangered red-cockaded woodpeckers (Picoides borealis), which invest considerable time excavating cavities in living pine trees [68].

Prescribed fire is applied for restoring and maintaining the maximum biodiversity, but other silvicultural practices such as tree thinning and variable retention harvesting, in combination with browsing or mechanical or chemical application to control understory trees, are potential alternatives to fire for achieving open conditions [5]. Although prescribed burns are more common in the Southeast than other regions, restoration through prescribed burns typically occur at small scales because fire frequently has socioeconomic constraints, but the cumulative benefits are large. Once a certain threshold in a change of state is reached, and closed broadleaf forests are established, restoration of the historic fire regime alone may not return the open forest state immediately. Given presence of longleaf pine trees in the overstory and depending on the starting condition of herbaceous 
vegetation, fifteen years of frequent prescribed burning appears to restore specialist species of open longleaf pine ecosystems [69] but 65 years or more may be required for some herbaceous species if sites are irregularly burned, for a slash pine plantation on a former agricultural field [70]. Fire creates diversity by providing a range of conditions between open grasslands and closed forests, phenology cues from fire and smoke, and foundation tree species or genera. Herbaceous plants may require the light of open conditions and removal of organic debris and other mechanical barriers for germination. Fire importantly favors regrowth of herbaceous plants over slow-growing trees. For example, open longleaf pine forest is a biodiversity hotspot for temperate herbaceous plants $[9,71]$.

Vertebrate species considered 'edge' or 'successional' require both forest and herbaceous components, which open forests supply without separation in space and time; therefore, these species generally may be more properly classified as open forest species [23]. Under the current baseline of overstory tree removal and continuous successional cycles, species classed as successional require management of transient clearings to generate foraging and nesting resources and clutter-free foraging space. However, this approach of spatially divided closed forest and clearings has not worked well for birds considered successional in the eastern United States, which are continuing to decline despite about $25 \%$ of landscapes in young forests where short rotation plantations occur [23]. Benefits of fire-maintained open forests also include a stable forest structure, allowing wildlife species to reach their lifetime reproductive potential without needing to relocate as forest conditions develop, as occurs in rapidly changing early successional habitats. Open forests provide space for birds and bats to forage in the clutter-free midstory, and support abundant insects, which are prey for some wildlife species. Equally, pollinator declines are not likely to be adequately addressed solely through provision of early successional forests [8].

Restoration of open pine and pine-oak forests will benefit disturbance-dependent wildlife, increase herbaceous plant cover and richness, and enhance local and landscape diversity and resiliency to climate change $[9,68,72]$. Some ecologists may support the idea that climate change and novel conditions make restoration futile, adding an unnecessary barrier to restoration, but instead of a nihilistic denial of restoration, changing conditions make action more urgent and beneficial to reduce risk. Southern pine and oak species typically are more drought- and heat-tolerant than other tree species present in the eastern United States; greater tolerance will protect against warming temperatures and flash droughts that may generate disastrous mortality in less tolerant broadleaf species. Lower density forests provide additional safeguards against drought while basal area $\leq 18.4 \mathrm{~m}^{2} \mathrm{ha}^{-1}$ is considered low risk for both southern pine beetle (Dendroctonus frontalis [20,22]). Restoration will help diverse species weather the additional stressors of climate change. Conservation initiatives are in place to increase the areal extent and restore fire-dependent longleaf pine and shortleaf pine ecosystems [73,74]. Even though investment is required, restoration may prove more beneficial in terms of forest health and maintenance of ecosystem services compared to inaction.

Funding: This research received no external funding.

Data Availability Statement: Forest Inventory and Analysis. 2021. Data available at: https:/ /apps. fs.usda.gov/fia/datamart/CSV/datamart_csv.html (accessed on 30 January 2021).

Acknowledgments: I thank the anonymous reviewers for their time and comments. This research was supported by the USDA Forest Service, Rocky Mountain Research Station. The findings and conclusions in this publication are those of the author and should not be construed to represent any official USDA or U.S. Government determination or policy.

Conflicts of Interest: The author declares no conflict of interest. 


\section{References}

1. Van Lear, D.H.; Carroll, W.; Kapeluck, P.; Johnson, R. History and restoration of the longleaf pine-grassland ecosystem: Implications for species at risk. For. Ecol. Manag. 2005, 211, 150-165. [CrossRef]

2. Richardson, D.M.; Rundel, P.W.; Jackson, S.T.; Teskey, R.O.; Aronson, J.; Bytnerowicz, A.; Wingfield, M.J.; Procheş, Ş. Human Impacts in Pine Forests: Past, Present, and Future. Annu. Rev. Ecol. Evol. Syst. 2007, 38, 275-297. [CrossRef]

3. Procheş, Ş.; Wilson, J.R.U.; Richardson, D.M.; Rejmánek, M. Native and naturalized range size in Pinus: Relative importance of biogeography, introduction effort and species traits. Glob. Ecol. Biogeogr. 2012, 21, 513-523. [CrossRef]

4. Mitchell, R.J.; Hiers, J.K.; O’Brien, J.J.; Jack, S.B.; Engstrom, R.T. Silviculture that sustains: The nexus between silviculture, frequent prescribed fire, and conservation of biodiversity in longleaf pine forests of the southeastern United States. Can. J. For. Res. 2006, 36, 2724-2736. [CrossRef]

5. Bragg, D.C.; Hanberry, B.B.; Hutchinson, T.F.; Jack, S.B.; Kabrick, J.M. Silvicultural options for open forest management in eastern North America. For. Ecol. Manag. 2020, 474, 118383. [CrossRef]

6. Noss, R.F. Forgotten Grasslands of the South: Washington, D.C.; Island Press: Washington, DC, USA, 2013; 320p.

7. Stoddard, H.L. Use of fire in pine forests and game lands of the deep Southeast. In Proceedings of the 1st Tall Timbers Fire Ecology Conference; Tall Timbers: Tallahassee, FL, USA, 1962; pp. 31-42.

8. Hanberry, B.B.; Bragg, D.C.; Alexander, H.D. Open forest ecosystems: An excluded state. For. Ecol. Manag. 2020, $472,118256$. [CrossRef]

9. Peet, R.K. Ecological classification of longleaf pine woodlands. In Longleaf Pine Ecosystems: Ecology, Silviculture, and Restoration; Jose, S., Jokela, E., Miller, D., Eds.; Springer: New York, NY, USA, 2006; pp. 51-93.

10. Semenova-Nelsen, T.A.; Platt, W.J.; Patterson, T.R.; Huffman, J.; Sikes, B.A. Frequent fire reorganizes fungal communities and slows decomposition across a heterogeneous pine savanna landscape. New Phytol. 2019, 224, 916-927. [CrossRef]

11. Gilliam, F.S.; Platt, W.J. Effects of long-term fire exclusion on tree species composition and stand structure in an old-growth Pinus palustris (longleaf pine) forest. Plant Ecol. 1999, 140, 15-26. [CrossRef]

12. Brown, H. Wildland burning by American Indians in Virginia. Fire Manag. Today 2000, 60, 29.

13. Fowler, C.; Konopik, E. The history of fire in the southern United States. Human Ecol. Rev. 2007, 14, 165-176.

14. Coughlan, M.R. Errakina: Pastoral Fire Use and Landscape Memory in the Basque Region of the French Western Pyrenees. J. Ethnobiol. 2013, 33, 86-104. [CrossRef]

15. Coughlan, M.R.; Nelson, D.R. Influences of Native American land use on the Colonial Euro-American settlement of the South Carolina Piedmont. PLoS ONE 2018, 13, e0195036. [CrossRef]

16. Hanberry, B.B.; Abrams, M.D.; Arthur, M.A.; Varner, J.M. Reviewing fire, climate, deer, and foundation species as drivers of historically open oak and pine forests and transition to closed forests. Front. For. Glob. Chang. 2020, 3, 56. [CrossRef]

17. Pan, Y.; Chen, J.M.; Birdsey, R.; McCullough, K.; He, L.; Deng, F. Age structure and disturbance legacy of North American forests. Biogeosciences 2011, 8, 715-732. [CrossRef]

18. Lorimer, C.G. Historical and ecological roles of disturbance in eastern North American forests: 9000 Years of change. Wildl. Soc. Bull. 2001, 29, 425-439.

19. Elsner, J.B.; Jagger, T.H.; Liu, K.-B. Comparison of Hurricane Return Levels Using Historical and Geological Records. J. Appl. Meteorol. Clim. 2008, 47, 368-374. [CrossRef]

20. Burkhart, H.E.; Haney, H.L., Jr.; Newberry, J.D.; Leuschner, W.A.; Morris, C.L.; Reed, D.D. Evaluation of thinning for reduction of losses from southern pine beetle attack in loblolly pine stands. South. J. Appl. For. 1986, 10, 105-108. [CrossRef]

21. Mitchell, R.J.; Duncan, S.L. Range of Variability in Southern Coastal Plain Forests: Its Historical, Contemporary, and Future Role in Sustaining Biodiversity. Ecol. Soc. 2009, 14, 17. [CrossRef]

22. Dickens, E.D.; Moorhead, D.J. A Guide to Thinning Pine Plantations; University of Georgia: Athens, GA, USA, 2015; Available online: https://bugwoodcloud.org/bugwood/productivity/pdfs/Guide_thinning_pine_plantations.pdf (accessed on 25 July 2021).

23. Hanberry, B.B.; Thompson, F.R., III. Open forest management for early successional birds. Wildl. Soc. Bull. 2019, 43, 141-151. [CrossRef]

24. Hanberry, B. Defining the Historical Northeastern forested boundary of the Great Plains Grasslands in the United States. Prof. Geogr. 2019, 72, 1-8. [CrossRef]

25. Oswalt, C.M.; Cooper, J.A.; Brockway, D.G.; Brooks, H.W.; Walker, J.L.; Connor, K.F.; Oswalt, S.N.; Conner, R.C. History and Current Condition of Longleaf Pine in the Southern United States; U.S. Department of Agriculture Forest Service, Southern Research Station: Asheville, NC, USA, 2012.

26. Glitzenstein, J.S.; Platt, W.J.; Streng, D.R. Effects of Fire Regime and Habitat on Tree Dynamics in North Florida Longleaf Pine Savannas. Ecol. Monogr. 1995, 65, 441-476. [CrossRef]

27. Stambaugh, M.C.; Guyette, R.P.; Marschall, J.M. Longleaf pine (Pinus palustris Mill.) fire scars reveal new details of a frequent fire regime. J. Veg. Sci. 2011, 22, 1094-1104. [CrossRef]

28. Delcourt, H.R. Presettlement vegetation of the North of Red River Land District, Louisiana. Castanea 1976, 41, 122-139.

29. Frost, C.C. Four centuries of changing landscape patterns in the longleaf pine ecosystem. In The Longleaf Pine Ecosystem: Ecology, Restoration, and Management, Proceedings of the Tall Timbers Fire Ecology Conference, No. 18, Tallahassee, FL, USA, 3-6 November 1993; Hermann, S.M., Ed.; Tall Timbers Research: Tallahassee, FL, USA, 1993; pp. 17-43. 
30. Predmore, S.A. Presettlement Forests and Fire in Escambia and Covington Counties, Alabama. Master's Thesis, University of Alabama, Auburn, AL, USA, 2007.

31. Bragg, D.C.; Bragg, H.A. Historical and contemporary environmental context for the Saline-Fifteen site (3BR119). Ark. Archeol. 2016, 55, 1-30.

32. Hanberry, B.B.; Brzuszek, R.F.; Foster, H.T.; Schauwecker, T.J. Recalling open old growth forests in the Southeastern Mixed Forest province of the United States. Écoscience 2019, 26, 11-22. [CrossRef]

33. Dayton, P.K. Toward an understanding of community resilience and the potential effects of enrichments to the benthos at McMurdo Sound, Antarctica. In Conservation Problems in Antarctica, Proceedings of the Colloquium on Conservation Problems in Antarctica, Blacksburg, VA, USA, 10-12 September 1971; Parker, B.C., Ed.; Allen Press: Lawrence, KS, USA, $1972 ;$ pp. 81-96.

34. Mohr, C.T.; Roth, F. The Timber Pines of the Southern United States; US Government Printing Office: Washington, DC, USA, 1897.

35. Mattoon, W.R. Life History of Shortleaf Pine; US Department of Agriculture: Washington, DC, USA, 1915.

36. Burns, R.M.; Honkala, B.H. Silvics of North America: 1. Conifers; Agriculture Handbook 654; USDA Forest Service: Washington, DC, USA, 1990.

37. Conner, R.C.; Hartsell, A.J. Forest area and conditions. In Southern Forest Resource Assessment; Wear, D.N., Greis, J.G., Eds.; GTR SRS-53; USDA Forest Service, Southern Research Station: Asheville, NC, USA, 2002; pp. 357-402.

38. Maizel, M.; White, R.D.; Root, R.; Gage, S.; Stitt, S.; Osborne, L.; Muehlbach, G. Historical Interrelationships between Population Settlement and Farmland in the Conterminous United States, 1790 to 1992. 1998. Available online: https://archive.usgs.gov/ archive/sites/landcover.usgs.gov/luhna/chap2.html (accessed on 21 May 2020).

39. Oswalt, C.M. Broad Scale Inventory of Shortleaf Pine. 2013. Available online: http://shortleafpine.net/why-shortleaf/fia-data (accessed on 17 January 2021).

40. Frost, C.C. History and future of the longleaf pine ecosystem. In The Longleaf Pine Ecosystem: Ecology, Silviculture, and Restoration; Jose, S., Jokela, E.J., Miller, D.L., Eds.; Springer: New York, NY, USA, 2006; pp. 9-48.

41. Haynes, R.W. Forest management in the 21st century: Changing numbers, changing context. J. For. 2002, 100, $38-43$.

42. Martin, W.H.; Boyce, S.G. Introduction: The southeastern setting. In Biodiversity of the Southeastern United States: Lowland Terrestrial Communities; Martin, W.H., Boyce, S.G., Echternacht, A.C., Eds.; John Wiley \& Sons: Hoboken, NJ, USA, 1993; pp. 1-46.

43. Prestemon, J.P.; Abt, R.C. Timber products supply and demand. In Southern Forest Resource Assessment; Wear, D.N., Greis, J.G., Eds.; USDA Forest Service, Southern Research Station: Asheville, NC, USA, 2002; pp. 299-324.

44. Oswalt, S.N.; Smith, W.B.; Miles, P.D.; Pugh, S.A. Forest Resources of the United States, 2017: A Technical Document Supporting the Forest Service 2020 RPA Assessment; U.S. Department of Agriculture, Forest Service, Washington Office: Washington, DC, USA, 2019.

45. Landers, B.J.L.; Lear, D.H.V.; Boyer, W.D. The longleaf pine forests of the Southeast: Requiem or renaissance. J. For. 1995, 93, 39-44.

46. South, D.B.; Johnson, E.E.; Hainds, M.J.; VanderSchaaf, C.L. Restoring longleaf pine on an agricultural site by planting alternating rows of slash pine: A case study. South. J. Appl. For. 2012, 36, 118-125. [CrossRef]

47. Forest Inventory and Analysis. 2021. Available online: https://apps.fs.usda.gov/fia/datamart/CSV/datamart_csv.html (accessed on 30 January 2021).

48. Bechtold, W.A.; Patterson, P.L. The Enhanced Forest Inventory and Analysis Program-National Sampling Design and Estimation Procedures; USDA Southern Research Station: Asheville, NC, USA, 2005.

49. Hanberry, B.; Hansen, M.H. Latitudinal range shifts of tree species in the United States across multi-decadal time scales. Basic Appl. Ecol. 2015, 16, 231-238. [CrossRef]

50. Ecomap. National Hierarchical Framework of Ecological Units; USDA Forest Service: Washington, DC, USA, 1993.

51. Hanberry, B.B.; Hanberry, P.; Riffell, S.K.; DeMarais, S.; Jones, J.C. Bird assemblages of intensively established pine plantations in Coastal Plain Mississippi. J. Wildl. Manag. 2012, 76, 1205-1214. [CrossRef]

52. Homer, C.; Dewitz, J.; Jin, S.; Xian, G.; Costello, C.; Danielson, P.; Gass, L.; Funk, M.; Wickham, J.; Stehman, S.; et al. Conterminous United States land cover change patterns 2001-2016 from the 2016 National Land Cover Database. ISPRS J. Photogramm. Remote Sens. 2020, 162, 184-199. [CrossRef]

53. Hanberry, B.B. Recent shifts in shade tolerance and disturbance traits in forests of the eastern United States. Ecol. Process. 2019, 8, 32. [CrossRef]

54. Zachrisson, O. Influence of forest fires on the north Swedish boreal forest. Oikos 1977, 29, 22-32. [CrossRef]

55. Seischab, F.K.; Bernard, J.M. Pitch pine (Pinus rigida Mill.) communities in central and western New York. Bull. Torrey Bot. Club 1991, 118, 412-423. [CrossRef]

56. Minnich, R.A.; Barbour, M.G.; Burk, J.H.; Fernau, R.F. Sixty Years of Change in Californian Conifer Forests of the San Bernardino Mountains. Conserv. Biol. 1995, 9, 902-914. [CrossRef]

57. Fulé, P.Z.; Covington, W.W.; Moore, M.M. Determining reference conditions for ecosystem management of southwestern ponderosa pine forests. Ecol. Appl. 1997, 7, 895-908. [CrossRef]

58. Taylor, A.H. Fire regimes and forest changes in mid and upper montane forests of the southern Cascades, Lassen Volcanic National Park, California, U.S.A. J. Biogeogr. 2000, 27, 87-104. [CrossRef]

59. Welch, N.; Waldrop, T.; Buckner, E. Response of southern Appalachian table mountain pine (Pinus pungens) and pitch pine (P. rigida) stands to prescribed burning. For. Ecol. Manag. 2000, 136, 185-197. [CrossRef] 
60. Pinto, F.; Romaniuk, S.; Ferguson, M. Changes to preindustrial forest tree composition in central and northeastern Ontario, Canada. Can. J. For. Res. 2008, 38, 1842-1854. [CrossRef]

61. Brūmelis, G.; Strazds, M.; Eglava, Ž. Stand structure and spatial pattern of regeneration of Pinus sylvestris in a natural treed mire in Latvia. Silva Fenn. 2009, 43, 767-781. [CrossRef]

62. Fulé, P.Z.; Korb, J.E.; Wu, R. Changes in forest structure of a mixed conifer forest, southwestern Colorado, USA. For. Ecol. Manag. 2009, 258, 1200-1210. [CrossRef]

63. Bekker, M.F.; Taylor, A.H. Fire disturbance, forest structure, and stand dynamics in montane forests of the southern Cascades, Thousand Lakes Wilderness, California, USA. Écoscience 2010, 17, 59-72. [CrossRef]

64. Konstantinov, A.V. Changes in resilience to fire disturbance in lowland pine forest ecosystems. Biol. Bull. 2011, 38, 974-979. [CrossRef]

65. Rubiales, J.M.; Morales-Molino, C.; Álvarez, S.G.; García-Antón, M. Negative responses of highland pines to anthropogenic activities in inland Spain: A palaeoecological perspective. Veg. Hist. Archaeobot. 2011, 21, 397-412. [CrossRef]

66. Hanberry, B.B.; Dey, D.C. Historical range of variability for restoration and management in Wisconsin. Biodivers. Conserv. 2019, 28, 2931-2950. [CrossRef]

67. Hanberry, B.B.; Kabrick, J.M.; He, H.S.; Palik, B. Historical trajectories and restoration strategies for the Mississippi River Alluvial Valley. For. Ecol. Manag. 2012, 280, 103-111. [CrossRef]

68. Means, D.B. Vertebrate faunal diversity in longleaf pine savannas. In Longleaf Pine Ecosystems: Ecology, Management, and Restoration; Jose, S., Jokela, E., Miller, D., Eds.; Springer: New York, NY, USA, 2006; pp. 155-213.

69. Steen, D.A.; Conner, L.M.; Smith, L.L.; Provencher, L.; Hiers, J.K.; Pokswinski, S.; Helms, B.S.; Guyer, C. Bird assemblage response to restoration of fire-suppressed longleaf pine sandhills. Ecol. Appl. 2013, 23, 134-147. [CrossRef]

70. Kirkman, L.K.; Coffey, K.L.; Mitchell, R.J.; Moser, E.B. Ground cover recovery patterns and life-history traits: Implications for restoration obstacles and opportunities in a species-rich savanna. J. Ecol. 2004, 92, 409-421. [CrossRef]

71. Means, D.B. Longleaf pine forest, going, going, ... In Eastern Old-Growth Forests: Prospects for Rediscovery and Recovery; Davis, M.B., Ed.; Island Press: Washington, DC, USA, 1996; pp. 210-229.

72. Darracq, A.K.; Boone, W.W., IV; McCleery, R.A. Burn regime matters: A review of the effects of prescribed fire on vertebrates in the longleaf pine ecosystem. For. Ecol. Manag. 2016, 378, 214-221. [CrossRef]

73. America's Longleaf Restoration Initiative. 2020. Available online: http://www.americaslongleaf.org (accessed on 17 January 2017).

74. Shortleaf Pine Initiative. 2021. Available online: http:/ / www.shortleafpine.net (accessed on 17 January 2021). 